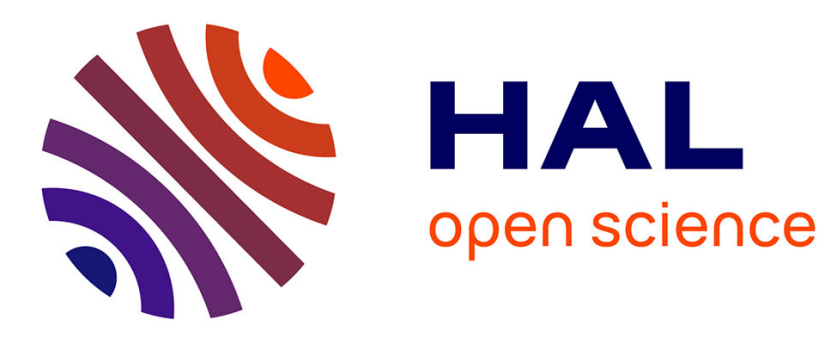

\title{
The colourful life of flowers
}

\author{
Sophie Nadot, Laetitia Carrive
}

\section{To cite this version:}

Sophie Nadot, Laetitia Carrive. The colourful life of flowers. Botany Letters, In press, 10.1080/23818107.2020.1839789 . hal-03024258

\section{HAL Id: hal-03024258 \\ https://hal.science/hal-03024258}

Submitted on 13 Jan 2021

HAL is a multi-disciplinary open access archive for the deposit and dissemination of scientific research documents, whether they are published or not. The documents may come from teaching and research institutions in France or abroad, or from public or private research centers.
L'archive ouverte pluridisciplinaire HAL, est destinée au dépôt et à la diffusion de documents scientifiques de niveau recherche, publiés ou non, émanant des établissements d'enseignement et de recherche français ou étrangers, des laboratoires publics ou privés. 


\section{The colourful life of flowers}

\section{Review article}

Sophie Nadot $^{1 *}$ and Laetitia Carrive ${ }^{1,2}$

${ }^{1}$ Ecologie Systématique Evolution, AgroParisTech, CNRS, Univ. Paris-Sud, Université ParisSaclay, Orsay, France

*Corresponding author - Orcid: 0000-0001-7521-8950 - Email: sophie.nadot@universiteparis-saclay.fr

Running head: Colour of flowers

\section{Abstract}

Flowers are the flagship structure of angiosperms (flowering plants). This spectacular innovation has probably contributed in a significant way to the extraordinary success of angiosperms, which today make up $90 \%$ of land plant species. Flowering plants display a beautiful and spectacular diversity of floral forms that results largely from the diversification of reproductive strategies, including co-adaptation with pollinators. One of the most spectacular variations concerns flower colour, with an almost endless range of shades varying from pure white to near black. In many plants, floral colours contrast with the rest of the plant, and are generally produced by the presence of pigments other than chlorophyll, although in some cases colour is created by light-reflecting structures. The biosynthetic pathways of carotenoids, anthocyanins and betalains, the three main classes pigment, have been deciphered. In many species, flower colour plays a key role in pollination as a visual cue to attract biotic pollinators. Although petals are often the most colourful and showy part of the flower, there are many exceptions, including examples where bracts are showier than the flowers themselves. Colour is usually stable within a species, resulting from adaptive processes linked to plant-pollinator relationships. The evolutionary and genetic mechanisms involved in flower colour shifts have been described in several taxa, providing insights into some of the processes that have shaped the diversity of flowering plants.

Keywords: flower, pigments, structural colour, pollination, selection 


\section{Introduction}

Flowers are ephemeral, beautiful, complex structures. They are the defining feature of angiosperms (flowering plants), which today make up approximately $90 \%$ of land plant biodiversity in terms of species number (Fiz-Palacios et al. 2011). This spectacular innovation has certainly contributed in a significant way to the extraordinary success of angiosperms, which have colonized almost all terrestrial, as well as several aquatic, environments. However, even today, the rapid emergence and diversification of angiosperms remain what Darwin had called more than a century and a half ago "an abominable mystery" (Davies et al. 2004). While the floral ground plan is similar across nearly all angiosperms in terms of general organization (see Nadot and Dodinet 2016 for a short review), an amazing diversity of floral forms has evolved resulting largely from the diversification of strategies to ensure reproduction, including co-adaptation with pollinators (see Selosse 2016 for a short review). One variable trait, which has been widely exploited in horticulture, is flower colour, with shades ranging from pure white to near black, as well as green as a result of the presence of chlorophyll, the pigment present in the vegetative aerial parts of plants that is directly involved in photosynthesis. The colour contrast between flowers and the rest of the plant is primarily due to the presence of pigments that belong to three main classes: carotenoids, anthocyanins and betalains (Miller et al. 2011). In some cases, colour is also produced by the presence of particular light-reflecting structures on the surface of perianth (Moyroud and Glover 2017). This colour contrast between vegetative and floral structures produces visual cues that attract biotic pollinating agents; showy flowers are therefore generally pollinated by animals, whereas small inconspicuous flowers, as found in grasses, sedges, nettle, oak and hazel, tend to be wind pollinated. Interestingly, comparisons with coloured reproductive structures of extant gymnosperms suggest that the coloured petals of early-diverging angiosperms may have evolved more for thermoregulation than for insect attraction (Rudall, 2020). In this review, we provide a brief overview of colour perception by insects, followed by a summary of the chemical and structural bases of colour production in plants, and the evolutionary and genetic mechanisms that account for the diversity in flower colour that we observe today.

\section{What pollinators see}

The colourful signals displayed by flowers indicate to pollinators (predominantly insects) the presence of nutritional resources and function as a guiding system towards the reproductive organs in order to ensure that pollen is transferred from the stamens of one flower to the pistils of a different flower, borne either on the same or on a different individual. This is the reason why many flowering plants have developed a system for guiding pollinators towards the centre of the flower, where the reproductive organs, and the resources sought by pollinators (mostly nectar and/or pollen), are located, promoting the involuntary transfer of pollen by the animal. The guiding system may involve scents and/or colours. Floral organs may be uniformly but differentially coloured, creating a strong contrast (Figure 1A), or there may be a colour contrast within a floral organ (Figure 1B). In many species, the perianth organs (usually the petals) present a more or less complex pattern of marks, spots, lines or dots often called "nectar guides" (Lunau 2000), which are not always visible to the human eye but are visible to many pollinating insects that can perceive colours towards the ultraviolet end of the spectrum. The perception of colour depends on the number of photoreceptors and the spectral range covered by these receptors, which varies considerably among species (Briscoe and Chttika 2001). Almost all Hymenoptera, the most important group of insect 
pollinators, have trichromatic colour vision with UV, blue and green photoreceptors that allow them to distinguish between leaves and flowers (Chittka et al. 1994). As shown by a study conducted on a community of neotropical plants mainly pollinated by bees and hummingbird (which have an additional red photoreceptor compared to Hymenoptera), the reflectance spectra of bee- and hummingbird-pollinated flowers differ significantly. Hummingbird-flowers predominantly reflected long wavelengths and were less conspicuous to bees, and bee-flowers presented more UV patterns, demonstrating that bees have colour preferences (de Camargo et al. 2019).

Several studies have demonstrated experimentally that these nectar guides increase pollinator attraction and play a major role in the reproductive success of plants by increasing pollen transfer (Thomas et al. 2009, Hansen et al. 2012, de Jager et al. 2017). In addition to the signal created by chemical colours, the conical epidermal cells found on the petals of many angiosperm species (Figure $1 \mathrm{C}$ ) also play a role in the visual signals perceived by pollinators by enhancing light absorption in perianth organs (Moyroud and Glover 2017). This has been shown experimentally in snapdragon (Antirrhinum majus L.), where flowers of a mutant with altered conical cell development appeared paler and duller than the wild-type, even though pigment composition was unaffected (Noda et al. 1994). Furthermore, some species may have elaborate perianth structures, such as the labellum of bee, spider and fly orchids, and the dark spots on the petals of Gorteria diffusa Thunb. that mimic the small beefly that pollinates this species (Johnson and Midgley 1997). These spots are produced by an elaborate iridescent three-dimensional structure composed of several cell types that differ in size, shape and pigmentation, contrasting with the orange background (Thomas et al. 2009).

\section{Where colours occur}

The most colourful part of the flower, i.e. where the major pollinator attracting signal is found, varies between different species. Hereafter, colour will refer to all colours except green, following de Candolle (1813) who considered colour as applying only to the non-green parts of a plant. In the majority of angiosperm species, petals are the most colourful (hence showy) floral organs. However, many species have developed other strategies where other floral organs are co-opted for pollinator attraction. For example, the small flowers of Albizia julibrissin Durazz. have long pink stamens producing attractive pompon-like inflorescences (Figure 1D). In Helleborus orientalis Lam. and in larkspurs, sepals are large and colourful (i.e. petaloid) whereas petals are small and function as nectar-storing organs (Figure 1E). In other species, the visual signal is displayed not in the flowers but in bracts, such as anthuriums, which have a large spathe surrounding inconspicuous flowers packed on a spadix, and Bougainvillea spectabilis Willd. where three brightly coloured bracts, surrounding three tiny white flowers, mimic a corolla. In some species all floral organs are brightly coloured, such as fuchsias whose many shades of pink are exclusively due to anthocyanins (Crowden et al. 1977) (Figure 1F) and whose pollen, despite being less visible at first, may also be coloured (Webby and Bloor 2000). Pollen grains are usually yellow, but red, white or blueish-purplish pollen are also found (Rose and Barthlott 1994, Lunau 1995), probably as a means to increase pollen transfer efficiency. In Cactaceae, bird-pollinated species produce red pollen, probably as part of the bird-flower syndrome (Rose and Barthlott 1994). Species with exposed anthers are more likely to produce coloured pollen than those with concealed anthers, to reduce the contrast between pollen and corolla and make pollen grains less visible to pollen thieves (Xiong et al. 2019). For instance, Trigona and Apis bees mostly act as pollen thieves by foraging for pollen while depositing negligible amounts of pollen on conspecific stigmas 
(Hargreaves et al. 2009). Pollen grains within a species may vary in colour. In Campanula americana, a herbaceous plant growing at the edge of forests in eastern USA, variation in pollen colour (with a prevalence of white and light purple in eastern populations and deep purple in western populations) was shown to be maintained by the specialist pollinator of this plant, Megachile campanulae (Ison et al. 2019). Lastly, coloured nectar has been recorded in several species, contributing to the visual cues involved in pollination systems (Hansen et al. 2007), as in Capsicum pubescens Ruiz \& Pav. where yellow nectar contrasts with a purple corolla.

\section{Making colours}

\section{Chemical colours}

Floral pigments are organic molecules that have the ability to absorb light energy and retain it during a fraction of a second. These molecules absorb specific wavelengths of light and reflect others, producing different colours according to their chemical nature. There are three main classes of floral pigments, each with different properties: carotenoids, anthocyanins and betalains (Tanaka et al. 2008, Miller et al. 2011).

Anthocyanins (from Ancient Greek 'ävvos' - anthos, flower, and ' $k u$ $\alpha v o{ }^{\prime}$ ' - kuanos, blue) are hydrophilic pigments that belong to the large flavonoid family (non-ketone polyhydroxy polyphenol compounds). They are specific to flowers and fruits to which they confer colours ranging from orange to blue, including red. They are synthesized in the cytosol and accumulate in the vacuoles of plant cells. Their biosynthetic pathway is well-known (Grotewold 2006) starting with phenylalanine and ending with the glycosylation of anthocyanidins as a last step (Figure 2A), and the genes involved in this pathway have been characterized and are conserved across seed plants (Piatkowski et al. 2020). In addition, the genetic basis of pigment variation in horticultural varieties has also been deciphered in certain species such as lilies (Lilium L.) (Yamagishi 2013). The colour produced by anthocyanins can change over time or can be affected by the $\mathrm{pH}$ of the cell, and by soil composition and $\mathrm{pH}$. Hydrangeas are a well-known example of how vacuolar $\mathrm{pH}$, determined in part by the complex interaction between pigments, co-pigments and metal ions, affects flower colour (Yoshida et al. 2013). Anthocyanins, although extremely common, are not the only flavonoids that are present in flowers. Chalcones are responsible for many pale-yellow flowers, such as yellow carnations (Dianthus caryophyllus L.) and chrysanthemums (Chrysanthemum x morifolium Ramat.) (Tanaka et al. 2008). In horticultural plants naturally lacking the blue delphinidin-based anthocyanin, blue flowers have been obtained by genetically manipulating the flavonoid biosynthesis pathway, resulting in blue roses, carnations and chrysanthemums (Tanaka 2006, Noda et al. 2013). The spatial distribution of pigment biosynthesis may vary within a flower, as in spotted petals. In Clarkia xantiana A.Gray, each petal has a red-purple spot produced by cyanidin-based and peonidin-based anthocyanins that contrasts with the pink background produced by malvidin-based anthocyanins. This spot results from the specific expression of genes involved in the cyanindin and peonidin biosynthesis pathways (Martins et al. 2013).

Betalains are tyrosine-derived pigments (Figure 2B) whose name comes from the Latin name for beetroot (Beta vulgaris L.). These pigments are only found in the order Caryophyllales, although they are synthesized in certain fungi (Tanaka et al. 2008, Gandia-Herrero and GarciaCarmona 2013). Betalains produce colours ranging from yellow, orange-red to violet, and give four o'clocks (Mirabilis jalapa L.), bougainvilleas and cacti their bright attractive colour. Like 
anthocyanins, these pigments are hydrophilic and accumulate in the vacuole. They replace anthocyanins in several families of this order. Both classes of pigments are mutually exclusive, although they can each combine with carotenoids. Betalains and anthocyanins share part of their biosynthetic pathway. It has been suggested that a shift in this pathway occurred in the ancestor of the core Caryophyllales, resulting in the production of betalains, followed by multiple reversals towards the production of anthocyanins notably in Caryophyllaceae and Molluginaceae (Brokington et al., 2011, 2015), although the alternative hypothesis with multiple origins of betalain pigmentation cannot be ruled out (Timoneda et al. 2019). Shifts between phenylalanine-rich and tyrosine-rich metabolism may be responsible for the shifts between anthocyanin and betalain pigmentation (Timoneda et al. 2019).

The colours yellow (e.g. dandelions), orange (e.g. marigolds) and orange-red (e.g. pheasant's eyes) are produced by carotenoids, which are lipophilic molecules with long chains of carbon (mostly 40 carbons). In flowers, carotenoids are synthesized in chromoplasts (Zhu et al. 2010) and sequestered in plastoglobules, which are lipid droplets (Bréhélin and Kessler 2008). The carotenoid biosynthesis pathway begins with isopentenyl pyrophosphate (Figure 2C) and takes place entirely in plastids. Carotenoid colour is influenced by the number of double bonds in the carbon chain (Miller et al. 2011). Most carotenoids found in flowers are xanthophylls, which are responsible for colours that range from pale to deep yellow (Tanaka et al. 2008). Beyond their role as floral pigments, carotenoids play a major role in photosynthesis and are vital to plants.

\section{Structural colours}

Structural colours result from the physical properties of surfaces that reflect light in a specific way. Such colours have long been known in butterflies, which have scales on their wings that are organized in such a way that coloured patterns can be obtained, mimicking pigments. In plants, scientists have focused on the chemical signals produced to attract pollinators (chemical colours or scents for example) and have neglected the role of structural colours. Only recently have the physical characteristics involved in the production of visual cues in certain flowers, where petal colour varies with the angle of observation, gained attention, and have been deciphered (reviewed in Moyroud and Glover 2017). In these flowers, the petal surface is covered partly or entirely with nanostructures that reflect light in different ways, creating colour by diffraction and resulting in an effect called "iridescence". This so-called structural colour can be superimposed over chemical colours. Structural colours have been observed in Hibiscus trionum L. (Vignolini et al. 2015) (Figure 3A) and in the spectacular black tepals of the tulip cultivar "Queen of the night" (Vignolini et al., 2013). It has been shown that the way in which nanostructures are organised on the surface has an effect on pollinator attraction (Moyroud et al. 2017). Some species combine structures and pigments to enhance the visual signals produced to attract pollinators. For instance, the glossy yellow petals of buttercups and lesser celandine have a very thin epidermis filled with yellow carotenoid pigments and innermost layers containing starch granules (Figure 3B). The thin epidermis acts as a film that reflects light, and the backscattering starch layer enhances brilliance, the two combined creating a gloss effect (Vignolini et al. 2012; van der Kooi et al. 2017). A similar phenomenon is observed in the California poppy (Eschscholzia californica Cham.) whose petals owe their bright orange colour to carotenoids and their silky aspect to the dense network of thin parallel ridges striating the epidermis (Wilts et al. 2018). In addition to facilitating pollinators' physical handling of the flower (Whitney et al. 2009), conical cells can also play a role in the perception of colour by pollinators by creating a three-dimensional 
surface on the epidermis, as mentioned above. Their presence increases light absorption by the pigments, thus enhancing colour saturation in the petals as seen in the Antirrhinum mixta mutant, which may provide stronger cues to pollinators (Gorton and Vogelmann 1996).

\section{Playing with colour}

The relationship between floral phenotype and pollination has been recognized since the $18^{\text {th }}$ century and numerous botanists, including Charles Darwin, acknowledged the idea that particular combinations of floral characters indicate specialized pollination (Fenster et al. 2004). The concept of pollination syndrome was introduced in the $19^{\text {th }}$ century by Federico Delpino and was defined as a combination of floral traits that have evolved as a response to selective pressures exerted by various categories of pollen vectors, whether abiotic (wind, water) or biotic (insects, mammals, birds) (Fenster et al. 2004). When biotic vectors are involved, these floral traits are directed towards attracting animals that feed on floral resources or use flowers to breed. Floral characters that are involved in pollination syndromes are essentially form, scent, reward such as nectar, oils and resins (although pollen may also play a role (Saunders 2012)), and colour (Fenster et al. 2004). For example, scentless red flowers that produce large amounts of nectar are likely to be pollinated by nectar-feeding birds like hummingbirds. Nectarivorous birds are particularly common in tropical and subtropical regions and are absent from the Palearctic realm (Cronk and Ojeda 2008), which accounts for the absence of red flowers from European and Asian floras. Shifts from insect pollination towards bird pollination have occurred in many lineages during the evolutionary history of angiosperms and are associated with modifications of the anthocyanin biosynthesis pathway (Rausher 2008, Thompson and Wilson 2008), resulting in significant differences in the chromatic cues provided by flowers (Shrestha et al. 2013). Scented white flowers with a long floral tube that open at night are likely to be pollinated by moths, which are attracted from a long distance by the scent, and when close by the reflection of light on the corolla (Fenster et al. 2004). Large scented white to pale yellow cup-shaped flowers producing nectar have evolved repeatedly in several tropical lineages of flowering plants as an adaptation to pollination by nectarivorous bats (Fleming et al. 2009). The pollination syndrome concept has been challenged by Ollerton et al. (2009) using plant communities from various geographical origins. They found that relatively few plant species corresponded to the floral syndromes as traditionally described, advising that it would be risky to rely solely on floral traits to infer the pollination system. However, a recent comprehensive review of the pollination syndrome literature (Dellinger 2020) showed that the concept is in fact fairly robust, and that floral traits such as colour, shape and reward are reliably predictive, especially reward and corolla width.

Several studies have highlighted the major role of pollinator-mediated selection in the evolution of flower colour. Shifts in flower colour can take place abruptly, as they can be induced by a limited number of mutations, because the preferential attraction of certain pollinators can have a major effect on reproduction. This has been shown in Bradshaw \& Schemske's landmark experiment (2003) on Mimulus. They performed reciprocal interspecific crosses between Mimulus lewisii Pursh, with yellow flowers pollinated by bumblebees, and $M$. cardinalis Douglas ex. Benth, with red flowers pollinated by hummingbirds. In both species, the presence or absence of carotenoids is controlled by a single locus, YELLOW UPPER (YUP). The introduction of the YUP allele of $M$. lewisii in $M$. cardinalis resulted in dark pink flowers, which received significantly more bee visits than the wild type. By contrast, the introduction 
of the yup allele of $M$. cardinalis in $M$. lewisii resulted in yellow-orange flowers, which received more visits by hummingbirds than the wild form. Thus, a single mutation resulting in colour change can lead to a shift in pollinator preference. A similar result was obtained when crossing Petunia integrifolia (Hook.) Shinz \& Tell. and P. axillaris (Lam.) Britton, Sterns \& Poggenb., two species whose difference in corolla colour is due to the absence or presence of anthocyanin pigmentation (Hoballah et al. 2007).

Pollination is not the only factor that influences the presence and diversity of floral colour in angiosperms. Abiotic factors and species richness also play a role in the structuration of colour diversity within and among plant communities: in communities where solar radiation is high and precipitation and net primary production are low, floral colours are more chromatic. Surprisingly, greater species richness is associated with less chromatically contrasted flowers (Dalrymple et al. 2020). At the macro-evolutionary scale, reconstructing the ancestral states of flower colour at the deepest nodes of the angiosperm phylogenetic tree is challenging, because this character is highly labile. However, it is possible to study the evolution of pollination syndromes at this large scale and thus make hypotheses on the evolution of flower colour. Since bird pollination, associated with red flowers, and moth pollination, associated with pure-white flowers, are derived pollination syndromes within angiosperms (Cronk and Ojeda 2008, Rosas-Guerrero et al. 2014), it seems unlikely that the flowers of the earliest angiosperms were either red or white. At the genus level, several studies have shown that major transitions in pollinator type were correlated with changes in flower shape and colour, which are two components of the pollination syndrome, as in Aquilegia L. (Whittall and Hodges 2007) and Schizanthus Ruiz \& Pav. (Perez et al. 2006) for example, where shifts from bee to moth or hummingbird pollination involved a transition in flower colour and spur length. Reversals from specialised pollination by hummingbirds, moths or bats towards less specialised insect pollination have been shown in Ruellia L. (Tripp and Manos 2008), indicating that specialization is not necessarily an evolutionary dead end. The transition from blue to red pigmentation is nevertheless more common than the reverse because the former often involves mutations resulting in the inactivation of branches of the anthocyanin pathway (Rausher 2008). This is the case in the genus Penstemon Schmidel, where the evolutionary transition from blue to red flowers involves the functional inactivation and degeneration of an enzyme from the anthocyanin pathway, resulting in the biosynthesis of pelargonidin-based anthocyanins instead of the delphinidin-based pigments that give blue flowers their colour (Wessinger and Rausher 2014).

The environmental changes that are induced by anthropogenic activities (climate change, rapidly increasing urbanization) may induce in turn accelerated responses from plants. A survey of UV pigmentation (mainly due to flavonoid pigments such as flavonols and flavones) in flowers of herbarium specimens has shown an effect of ozone decline across the second half of the $20^{\text {th }}$ century on UV pigmentation (Koski et al. 2020). Global changes may therefore affect the interaction with major pollinators such as bees.

\section{Changing colour in space}

A number of plant species are polymorphic for flower colour, which has long intrigued botanists. Several studies have revealed the major role of pollinator-mediated selection in maintaining flower colour polymorphism within a species. This was shown experimentally in populations of Mimulus aurantiacus Curtis from south-western California, which present a heritable colour polymorphism (Streisfeld and Kohn 2005). Coastal populations are redflowered and hummingbird-pollinated, whereas inland populations have yellow flowers 
pollinated by hawkmoths. Hawkmoths showed a strong preference for yellow flowers even when these were transplanted to a coastal environment (Streisfeld and Kohn 2007). Floral colour polymorphism is particularly common in orchids, and the means by which this is maintained differ among species. In Orchis mascula L., the low level occurrence of whiteflowered or light pink-flowered individuals has been shown to increase the reproductive success of the dominant purple-flowered morph, probably through kin selection (Schatz et al. 2013). Another mechanism is involved in maintaining flower colour polymorphism in the elder-flowered orchid (Dactylorhiza sambucina (L.) Soó), which is common in European subalpine and alpine grasslands. Here, the spectacular colour polymorphism (pale yellowflowered and purple-flowered individuals coexist in most natural populations) is maintained by negative frequency-dependent selection through pollinator preference for rare morphs. The reproductive success of one morph increases as its relative frequency decreases, because its attractiveness towards pollinators (bumblebees) increases compared to the other morph (Gigord et al. 2001). A similar mechanism has been described in Clarkia xantiana A.Gray where natural populations are polymorphic for the presence or absence of red and white spots on the pink petals. Among the various bee species that pollinate these flowers, two species showed negative frequency-dependent foraging, preferring to visit the morph (spotted or unspotted) that was in the minority within a population (Eckhart et al. 2005). In Lysimachia arvensis (L.) U.Manns \& Anderb. (Figure 4A and B), the blue-flowered form is better adapted to xeric conditions than the red-flowered form, which accounts for its high frequency in the Mediterranean region compared to the red form (Ortiz et al. 2015). A difference in herkogamy between these morphs was recently described, blue flowers showing approach herkogamy while red flowers showed reverse herkogamy, with an effect on pollen deposition (Jiménez- López et al. 2020). Colour polymorphism is frequent in species with deceptive pollination, and this may be due to disruptive selection caused by inaccurate discrimination by pollinators (Kagawa and Takimono 2016). Floral colour polymorphism may also be driven by selection via non-pollinating agents, genetic drift or gene flow, as shown by a survey of this phenomenon in the Mediterranean basin where it is found in many species belonging to several unrelated angiosperm families (Narbona et al. 2017).

A rare example of colour polymorphism concerning reproductive organs (instead of the perianth) has been described in Butomus umbellatus L., in which morphs with a white gynoecium contrasting with the common bright pink gynoecium were found in natural populations of China (Huang ant Tang 2008). This polymorphism is possibly maintained through asymmetric pollen-pistil interactions between the two morphs (Yang et al. 2013). In general, colour changes can be due to changes in pigment concentration or composition, and in the vast majority of cases anthocyanins are involved (Narbona et al. 2017).

It has to be noted that the role of selection in the evolution of floral traits, including flower colour, may vary according to species, and phenotypic selection is not necessarily the main driver (Harder and Johnson 2009). Many factors, such as herbivory (the same pigments may be involved both in floral display and leaf protection against herbivores), nutrient availability and vegetation context may influence selection on floral traits (Sletvold 2019). A recent study on Erica coccinea subsp. coccinea suggested that the yellow/red colour polymorphism of flowers is associated with regeneration mode and flowering phenology. Pollinators show no preference for red or yellow flowers, the lack of anthocyanins being responsible for the yellow colour, which has pleiotropic effects (Ojeda et al. 2019).

\section{Temporal changes in flower colour}


Several species of angiosperms have flowers that change colour during anthesis from the bud opening to wilting (Lunau 1996), a phenomenon that has been exploited for ornamental purposes. Spectacular examples of colour changes in garden plants include Weigela coraeensis Thunb. whose corolla turns from pale yellow to pink (Figure 4C), or Lantana camara L., also turning from yellow to pink but with much brighter shades, and Aesculus hippocastanum L. (Figure 4D). In the aforementioned examples, as in other species, colour change takes place right after pollination and has been interpreted as a visual cue for pollinators, allowing them to save energy by distinguishing flowers that have not been visited and have intact resources from flowers that have been visited and whose reward is depleted (Ram and Mathur 1984, Suzuki and Ohashi 2014). In Lantana, pollination triggers the rapid biosynthesis of delphinidin monoglucoside (anthocyanin), which masks the carotenoids already present and creates a shift from yellow to pink (Ram and Mathur 1984). The change in colour may also enhance male reproductive success by reducing geitonogamous pollination, as shown experimentally in the hemiparasitic species Pedicularis monbeigiana Bonati (Sun et al. 2005). Physiological constraints may also be involved in colour change, as evidenced in Fuchsia exorticata (G.Forst.) L.f. whose flowers turn from red to blue depending on age rather than pollination (Delph and Lively 1989). Age is also responsible for the change from blue to red observed in Lungwort flowers (Oberrath et al. 1995). Both blue and red flowers, play a role in the long-distance attractiveness of plants in Pulmonaria collina Sauer, although the blue flowers are less rewarding than the young red flowers, suggesting that colour change could be a mechanism to enhance the plant reproductive success (Oberrath and Bohning-Gaese 1999). Although temporal changes in flower colour have evolved repeatedly in flowering plants, its relatively low occurrence could be due to the complex balance of ecological factors that are involved in its emergence and maintenance (Ruxton \& Schaefer, 2016).

\section{Mimicry}

This adaptive strategy is found not only in plants but across many living organisms and refers to species that mimic other species to ensure their survival. It was first described by Bates (1861) in the seminal case study of butterflies where a harmless species mimics a toxic one. This phenomenon was later called Batesian mimicry. In plants, mimicry relying on colour is widespread in orchids where it is associated with pollination (Johnson and Schiestl 2016). Flowers of the red helleborine Cephalanthera rubra (L.) Rich. resemble those of the bellflower Campanula persicifolia L., without the reward (nectar). The bellflower is pollinated by two species of Megachilidae bees that shelter and nest within the flowers, harvesting pollen to feed their larvae. The insects are misled by the colour the orchid flowers, which they visit by mistake in addition to those of the bellflower (Nilsson, 1983). Numerous other cases of mimicry between non-rewarding and rewarding species from the same community have been described in various regions of the world (for example Jersáková et al. 2006, Newman et al. 2012, Lunau and Wester 2017).

\section{Conclusion}

The infinite colour palette that flowers display is the result of more than 150 million years of evolution, tightly linked to the evolution of pollination systems, which guarantee reproduction. Selective pressures coming from pollen vectors, whether biotic or abiotic, have driven the emergence of multiple strategies to attract animals using pigments and microstructures. However, although the molecular, chemical, physical and evolutionary 
processes at the origin of colour diversity have been more or less elucidated, there is one remaining question that has yet to find an answer: what was the colour of the ancestral angiosperm flower?

\section{Acknowledgements}

We thank the Société Nationale d'Horticulture de France for inviting us to give a talk on this subject, which gave us the idea of writing this review. We are also grateful to the members of the EVA team at ESE for warmly encouraging us to write this review.

\section{Author contributions}

SN and LC wrote the manuscript and designed the figures.

\section{References}

Bates HW. 1861. Contributions to an insect fauna of the Amazon valley. Lepidoptera: Heliconidae. Trans. Linn. Soc. Lond. 23:495-566.

Bradshaw HD, Schemske DW. 2003. Allele substitution at a flower colour locus produces a pollinator shift in monkeyflowers. Nature. 426:176-178.

Bréhélin C, Kessler F. 2008. The Plastoglobule: A Bag Full of Lipid Biochemistry Tricks. Photochem. Photobiol. 84:1388-1394.

Briscoe AD, Chittka L. 2001. The evolution of color vision in insects. Annu. Rev. Entomol. 46:471-510

Brockington SF, Walker RH, Glover BJ, Soltis PS., Soltis DE. 2011. Complex pigment evolution in the Caryophyllales: Research review. New Phytol. 190:854-864.

Brockington SF, Yang Y, Gandia-Herrero F, Covshoff S, Hibberd J M, Sage RF, Wong GKS, Moore MJ, Smith $\mathrm{SA}$, 2015. Lineage-specific gene radiations underlie the evolution of novel betalain pigmentation in Caryophyllales. New Phytol. 207:1170-1180.

Chittka L, Shmida A, Troje N, Menzel R. 1994. Ultraviolet as a component of flower reflections, and the colour perception of Hymenoptera. Vision Res. 34:1489-1508.

Cronk Q, Ojeda I. 2008. Bird-pollinated flowers in an evolutionary and molecular context. J. Exp. Bot. 59:715-727.

Crowden RK, Wright J, Harborne JB. 1977. Anthocyanins of Fuchsia (Onagraceae). Phytochemistry 16:400402.

Dalrymple RL, Kemp DJ, Flores-Moreno H, Laffan SW, White TE, Hemmings FA, Moles AT. 2020. Macroecological patterns in flower colour are shaped by both biotic and abiotic factors. New Phytol. DOI: 10.1111/nph.16737.

Davies TJ, Barraclough TG, Chase MW, Soltis PS, Soltis DE, Savolainen V. 2004. Darwin's abominable mystery: insights from a supertree of the angiosperms. Proc. Natl. Acad. Sci. 101:1904-1909.

de Camargo MGG, Lunau K, Batalha MA Brings S, de Brito VLG, Morellato LPC. 2019. How flower colour signals allure bees and hummingbirds: a community-level test of the bee avoidance hypothesis. New Phytol. 222:1112-1122.

de Candolle AP. 1813. Théorie élémentaire de la botanique. Paris: Déterville

de Jager ML, Willis-Jones E, Critchley S., Glover BJ. 2017. The impact of floral spot and ring markings on pollinator foraging dynamics. Evol. Ecol. 31:193-204.

.Dellinger A. 2020. Pollination syndromes in the 21st century: where do we stand and where may we go? New Phytol. DOI: 10.1111/nph.16793.

Delph LF, Lively CM. 1989. The evolution of floral color change: pollinator attraction versus physiological constraints in Fuchsia excorticata. Evolution 43:1252-1262.

Eckhart VM, Rushing NS, Hart GM, Hansen JD. 2006. Frequency-dependent pollinator foraging in polymorphic Clarkia xantiana ssp. xantiana populations: implications for flower colour evolution and pollinator interactions. Oikos. 112:412-421. 
Fenster CB, Armbruster WS, Wilson P, Dudash MR, Thomson JD. 2004. Pollination Syndromes and Floral Specialization. Ann. Rev. Ecol. Evol. Syst. 35:375-403.

Fiz-Palacios O, Schneider H, Heinrichs J, Savolainen V. 2011. Diversification of land plants: insights from a family-level phylogenetic analysis. BMC Evol Biol 11: article number 341.

Fleming TH, Geiselman C, Kress WJ. 2009. The evolution of bat pollination: a phylogenetic perspective. Ann. Bot. 104:1017-1043.

Gandia-Herrero F, Garcia-Carmona F. 2013. Biosynthesis of betalains: yellow and violet plant pigments. Tr. Pl. Sci. 18:334-343.

Gigord LDB, Macnair MR, Smithson A. 2001. Negative frequency-dependent selection maintains a dramatic flower color polymorphism in the rewardless orchid Dactylorhiza sambucina (L.) Soo. Proc. Natl. Acad. Sci. 98:6253-6255.

Gorton H, Vogelmann TC. 1996. Effects of epidermal cell shape and pigmentation on optical properties of Antirrhinum petals at visible and ultraviolet wavelengths. Plant Physiol. 112:879-8238.

Grotewold E. 2006. The genetics and biochemistry of floral pigments. Ann. Rev. Plant Biol. 57:761-780.

Hansen DM, Olesen JM, Mione T, Johnson SD, Müller CB. 2007. Coloured nectar: distribution, ecology, and evolution of an enigmatic floral trait. Biol. Rev. 82:83-111.

Hansen DM, Van der Niet T, Johnson SD. 2012. Floral signposts: testing the significance of visual 'nectar guides' for pollinator behaviour and plant fitness. Proc. R. Soc. B: Biological Sciences 279:634-639.

Harder LD, Johnson SD. 2009. Darwin's beautiful contrivances: evolutionary and functional evidence for floral adaptation. New Phytol. 183:530-545.

Hargreaves AL, Harder LD, Johnson SD. 2009. Consumptive emasculation: the ecological and evolutionary consequences of pollen theft. Biol. Rev. 84:259-276.

Hoballah ME, Gubitz T, Stuurman J, Broger L, Barone M, Mandel T, Dell'Olivo A, Arnold M, Kuhlemeier C, 2007. Single Gene-Mediated Shift in Pollinator Attraction in Petunia. Plant Cell. 19:779-790.

Huang SQ, Xiao-Xin Tang XX. 2008. Discovery of Gynoecium Color Polymorphism in an Aquatic Plant. J. Integr. Plant Biol. 50:1178-1182.

Ison JL, Tuan ESL, Koski MH, Whalen JS, Galloway LF. 2019. The role of pollinator preference in the maintenance of pollen colour variation. Ann. Bot. 123:951-960.

Jersáková J, Johnson SD, Kindlmann P. 2006. Mechanisms and evolution of deceptive pollination in orchids. Biol. Rev. 81:219-235.

Jiménez-López FJ, Ortiz PL, Talavera M, Pannell JR, Arista M. 2020. The role of lateral and vertical herkogamy in the divergence of the blue- and red-flowered lineages of Lysimachia arvensis. Ann. Bot. 125:11271135.

Johnson SD, Shiestl F. 2016. Floral mimicry. Oxford: Oxford University Press.

Johnson SD, Midgley JJ. 1997. Fly pollination of Gorteria diffusa (Asteraceae), and a possible mimetic function for dark spots on the capitulum. Am. J. Bot. 84:429-436.

Kagawa K, Takimoto G. 2016. Inaccurate color discrimination by pollinators promotes evolution of discrete color polymorphism in food-deceptive flowers. Am. Nat. 187:194-204.

Koski MH, MacQueen D, Ashman TL. 2020. Floral pigmentation has responded rapidly to global change in ozone and temperature. Curr. Biol. 30:1-7.

Lunau K. 1995. Notes on the colour of pollen. Plant Syst. Evol. 198:235-252.

Lunau K. 1996. Unidirectionality of floral colour changes. PI. Syst. Evol. 200:125-140.

Lunau, K. 2000. The ecology and evolution of visual pollen signals. Plant Syst Evol. 222:89-111.

Lunau K, Wester P. 2017. Mimicry and Deception in Pollination. In Adv. Bot. Res. Elsevier, 259-279.

Martins TR, Berg JJ, Blinka S, Rausher MD, Baum DA. 2013. Precise spatial- temporal regulation of the anthocyanin biosynthetic pathway leads to petal spot formation in Clarkia gracilis (Onagraceae). New Phytol. 197: 958-969.

Miller R, Owens SJ, Rørslett B. 2011. Plants and colour: Flowers and pollination. Optics \& Laser Technol. 43:282-294.

Moyroud E., Glover BJ. 2017. The physics of pollinator attraction. New Phytol. 216:350-354. 
Moyroud E, Wenzel T, Middleton R, Rudall PJ, Banks H, Reed A, Mellers G, Killoran P, Westwood MM, Steiner U, Vignolini S, Glover BJ. 2017. Disorder in convergent floral nanostructures enhances signalling to bees. Nature. 550:469-474.

Nadot S, Dodinet E. 2016. Letters to the twenty-first century botanist: "What is a flower?". Botany Letters. 163: 9-10.

Narbona E, Wang H, Ortiz PL, Imbert E. 2017. Flower colour polymorphism in the Mediterranean Basin: occurrence, maintenance and implications for speciation. Plant Biol. 20(Suppl. 1):8-20.

Newman E, Anderson B, Johnson SD. 2012. Flower colour adaptation in a mimetic orchid. Proc. Royal Soc. B: Biol. Sci. 279:2309-2313.

Nilsson LA.,1983. Mimesis of bellflower (Campanula) by the red helleborine orchid Cephalanthera rubra. Nature. 305:799-800.

Nisar N, Li,L, Lu S, Khin NC, Pogson BJ. 2015. Carotenoid metabolism in plants. Molecular plant 8:68-82.

Noda K, Glover BJ, Linstead P, Martin C. 1994. Flower colour intensity depends on specialized cell shape controlled by a Myb-related transcription factor. Nature. 369: 661-664.

Noda N, Aida R, Kishimoto S, Ishiguro K, Fukuchi- Mizutaini M, Tanaka Y, Ohmiya A. 2013. Genetic engineering of novel bluer-colored Chrysanthemums pro- duced by accumulation of delphinidin-based anthocyanins. Plant Cell Physiol. 4: 1684-1695.

Oberrath R, Zanke C, Bohning-Gaese K. 1995. Triggering and ecological significance of floral color change in Lungwort (Pulmonaria spec.). Flora 190:155-159.

Oberrath R, Bohning-Gaese K. 1999. Floral color change and the attraction of insect pollinators in lungwort (Pulmonaria collina). Oecologia 121:383-391.

Ojeda F, Midgley J, Pauw A, Lavola A, Casimiro-Soriguer R, Hattas,D, Segarra- Moragues JG, JulkunenTiitto R. 2019. Flower colour divergence is associated with post-fire regeneration dimorphism in the fynbos heath Erica coccinea subsp. coccinea (Ericaceae). Evol. Ecol. 33:345-367.

Ollerton J, Alarco R, Waser NM, Price MV, Watts S, Cranmer L, Hingston A, Peter Cl, Rotenberry J. 2009. A global test of the pollination syndrome hypothesis. Ann. Bot. 103:1471-1480.

Ortiz PL, Berjano R, Talavera M, Rodríguez-Zayas L, Arista M. 2015. Flower colour polymorphism in Lysimachia arvensis: how is the red morph maintained in Mediterranean environments? PPEES. 17:142-150.

Pérez F, Arroyo M. T. K., Medel R, Hershkovitz MA. 2006. Ancestral reconstruction of flower morphology and pol- lination systems in Schizanthus (Solanaceae). Amer. J. Bot. 931029-931038.

Piatkowski BT, Imwattana K, Tripp EA, Weston DJ, Healey A, Schmutz J, Shaw AJ. 2020. Phylogenomics reveals convergent evolution of red-violet coloration in land plants and the origins of the anthocyanin biosynthetic pathway. Mol. Phyl. Evol. 151:106904.

Ram HYM, Mathur G. 1984. Flower colour changes in Lantana camara. J. Exp. Bot. 35:1656-1662.

Rausher MD. 2008. Evolutionary transitions in floral color. Int. J. Plant Sci. 169:7-21.

Rosas-Guerrero V, Aguilar R, Martén-Rodríguez S, Ashworth L, Lopezaraiza-Mikel M, Bastida JM, Quesada M. 2014. A quantitative review of pollination syndromes: do floral traits predict effective pollinators? Ecol. Letters. 17:388-400.

Rose MJ, Barthlott W. 1994. Coloured pollen in Cactaceae: a mimetic adaptation to hummingbirdpollination? Bot. Acta. 107: 402-406.

Rudall PJ. 2020. Colourful cones: how did flower colour first evolve? J. Exp. Bot., 71:759-767.

Ruxton GD, Schaefer HM. 2016. Floral colour change as a potential signal to pollinators. Curr. Op. PI. Biol. 32:96-100

Saunders RMK. 2012. The diversity and evolution of pollination systems in Annonaceae. Bot. J. Lin. Soc. 169: 222-244.

Schatz B, Delle-Vedove R, Dormont L. 2013. Presence, distribution and effect of white, pink and purple morphs on pollination in the orchid Orchis mascula. Eur. J. Env. Sci. 3:119-128.

Selosse MA. 2016. Letters to the twenty-first century botanist: "What is a flower?" (3) The flower as an evolutionary arms race: was Linnaeus' choice misleading? Botany Letters. 163: 231-235

Shrestha M, Dyer A, Boyd-Gerny S, Wong BBM, Burd M. 2013. Shades of red: bird-pollinated flowers target the specific colour discrimination abilities of avian vision. New Phytol. 198:301-310. 
Sletvold N. 2019. The context dependence of pollinator-mediated selection in natural populations. Int. J. Plant Sci. 180:934-943.

Streisfeld MA, Kohn JR. 2005. Contrasting patterns of floral and molecular variation across a cline in Mimulus aurantiacus. Evolution. 59:2548-2559.

Streisfeld MA, Kohn JR. 2007. Environment and pollinator-mediated selection on parapatric floral races of Mimulus aurantiacus. J. Evol. Biol. 20:122-132.

Sun SG, Liao K, Xia J, Guo YH. 2005. Floral colour change in Pedicularis monbeigiana (Orobanchaceae). PI. Syst. Evol. 255:77-85.

Suzuki MF, Ohashi K. 2014. How does a floral colour-changing species differ from its non-colour-changing congener? - a comparison of trait combinations and their effects on pollination. Funct. Ecol. 28:549-560.

Tanaka Y. 2006. Flower colour and cytochromes P450. Phytochem. Rev. 5:283-291.

Tanaka Y, Sasaki N, Ohmiya A. 2008. Biosynthesis of plant pigments: anthocyanins, betalains and carotenoids. Plant J. 54:733-749

Thomas MM, Rudall PJ, Ellis AG, Savolainen V, Glover BJ. 2009. Development of a complex floral trait: The pollinator-attracting petal spots of the beetle daisy, Gorteria diffusa (Asteraceae). Am. J. Bot. 96:2184-2196.

Thompson JD, Wilson P. 2008. Explaining evolutionary shifts between bee and hummingbird pollination: convergence, divergence, and bidirectionality. Int. J. Plant Sci. 169:23-38.

Timoneda A, Feng T, Sheehan H, Walker-Hale N, Pucker B, Lopez-Nieves S, Guo R, Brockington S. (2019). The evolution of betalain biosynthesis in Caryophyllales. New Phytol. 224:71-85.

Tripp EA, Manos PS. 2008. Is floral specialization an evolutionary dead-end? Pollination system transitions in Ruellia (Acanthaceae). Evolution. 32:1712-1737.

van der Kooi CJ, Elzenga JTM, Dijksterhuis J., Stavenga DG. 2017. Functional optics of glossy buttercup flowers. J. R. Soc. Interface. 14:20160933.

Vignolini S, Thomas MM, Kolle M, Wenzel T, Rowland A, Rudall PJ, Baumberg JJ, Glover BJ, Steiner U. 2012. Directional scattering from the glossy flower of Ranunculus: how the buttercup lights up your chin. J. R. Soc. Interface. 9:1295-1301.

Vignolini S, Moyroud E, Glover BJ, Steiner U. 2013. Analysing photonic structures in plants. J. R. Soc. Interface. 10:20130394.

Vignolini S, Moyroud E, Hingant T, Banks H, Rudall PJ, Steiner U, Glover BJ. 2015. The flower of Hibiscus trionum is both visibly and measurably iridescent. New Phytol. 205:97-101.

Webby R, Bloor S. 2000. Pigments in the Blue Pollen and Bee Pollen of Fuchsia excorticata. Z. Naturforsch. 55:503-505.

Wessinger CA, Rausher MD. 2014. Ecological transition predictably associated with gene degeneration. Mol. Biol. Evol. 32:347-354.

Whitney HM, Chittka L, Bruce TJA. 2009. Conical Epidermal Cells Allow Bees to Grip Flowers and Increase Foraging Efficiency. Curr. Biol. 19:948-953.

Whittall J, Hodges S. 2007. Pollinator shifts drive increasingly long nectar spurs in columbine flowers. Nature. 447:706-709.

Wilts BD, Rudall PJ, Moyroud E, Gregory T, Ogawa Y, Vignolini S, Steiner U, Glover BJ. 2018. Ultrastructure and optics of the prism-like petal epidermal cells of Eschscholzia californica (California poppy). New Phytol. 219:1124-1133.

Xiong YZ, Jia LB, Zhang C, Huang SQ. 2019. Color-matching between pollen and corolla: hiding pollen via visual crypsis? New Phytol. 224:1142-1150.

Yamagishi M. 2013. How genes paint lily flowers: Regulation of colouration and pigmentation patterning. Sci. Hort. 163:27-36.

Yang CF, Li J, Gituru RW, Wang QF, Guo YH. 2013. Aquatic Bot. 106: 29-34.

Yoshida K, Toyama-Kato Y, Kameda K, Kondo T. 2003. Sepal color variation of Hydrangea macrophylla and vacuolar pH measured with a proton-selective microelectrode. Plant Cell Physiol. 44 :262-268.

Zhu C, Bai C, Sanahuja G, Yuan D, Farré G, Naqvi S, Shi L, Capell T, Christou P. 2010 The regulation of carotenoid pigmentation in flowers. Arch. Biochem. Biophys. 504: 132-141. 

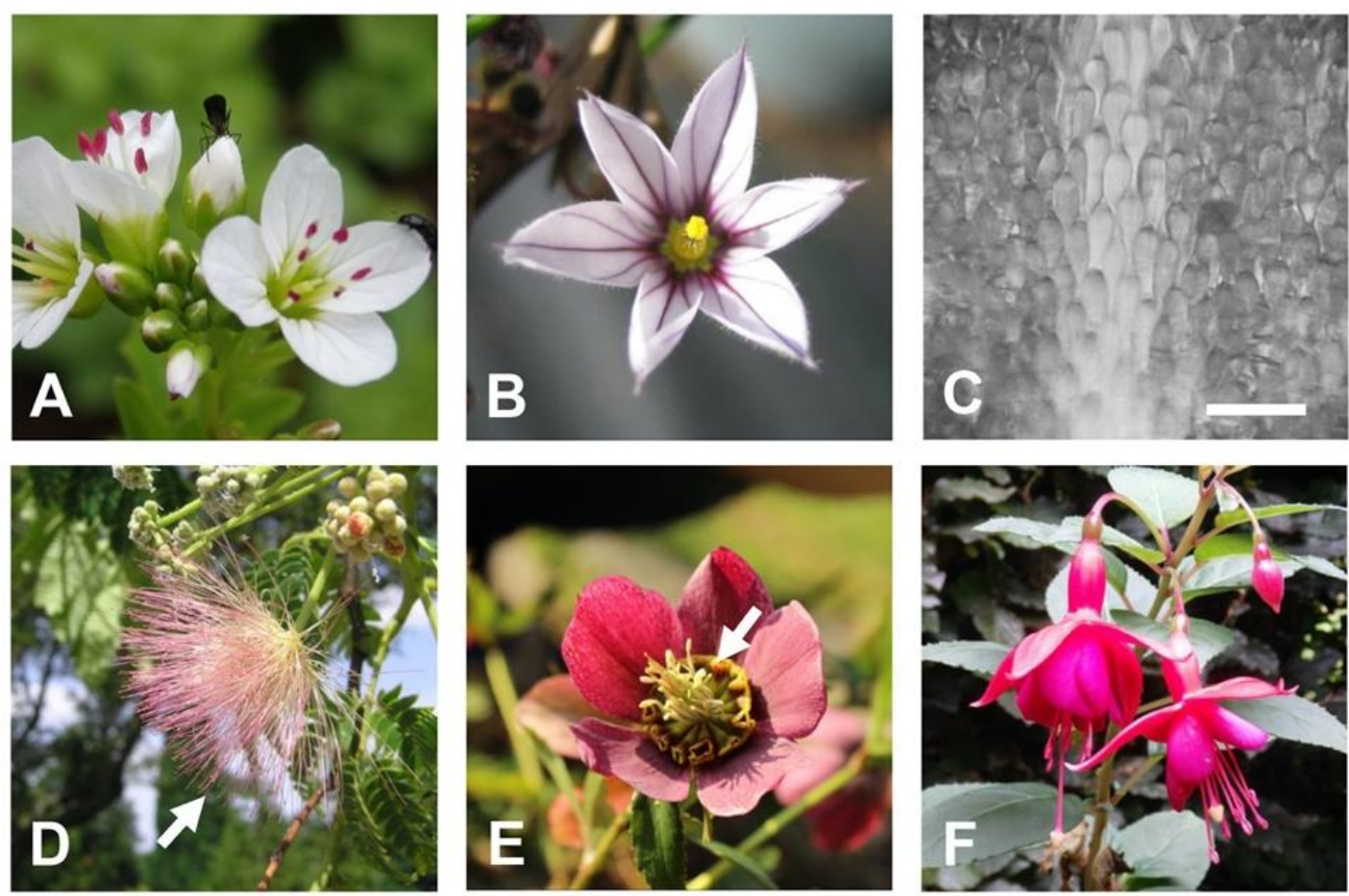

Figure 1. A. Flowers of Cardamine amara L. (Brassicaceae), showing a contrast between white petals and red anthers. B. Flower of Sisyrinchium scariosum I.M.Johnst. (Iridaceae) with darker lines and central spots on the tepals that guide floral visitors towards the centre of the flower where the rewards and reproductive organs are located. C. Inner tetal upper epidermis of Anemone nemorosa L. (Ranunculaceae) with conical cells that reflect light differently from the rest of the petal and allow pollinators to maintain a grip on the flower. Light microscopy. Scale bar: $100 \mu \mathrm{m}$. D. Globular inflorescence of Albizia julibrissin Durazz. (Fabaceae), each flower has small petals but conspicuous long pink stamens. E. Helleborus orientalis Lam. (Ranunculaceae)

flower with pink showy sepals and smal tubular nectariferous petals. F. Fuchsia sp.

(Onagraceae) flower with brightly coloured organs (sepals, petals, stamens and style).

Photographs: S. Nadot. 


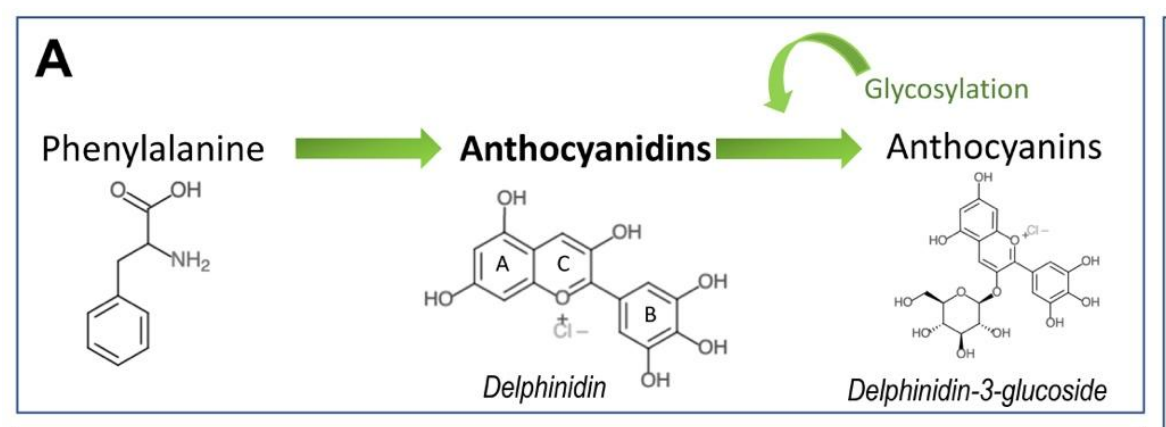

C

Isopentenyl diphosphate

B

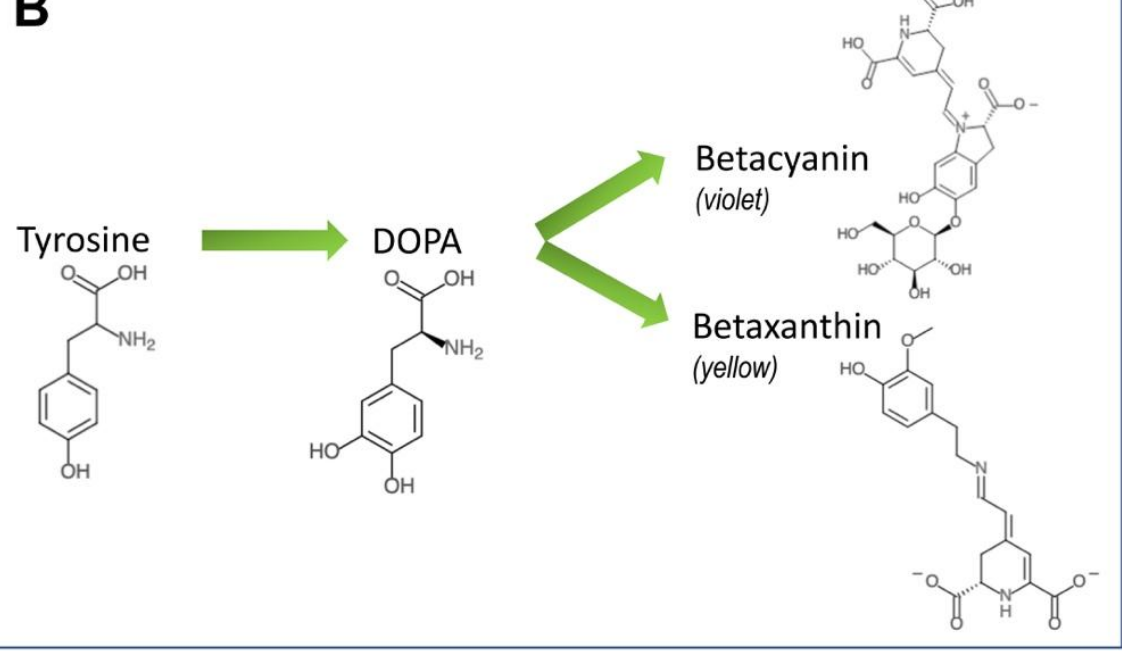

Geranylgeranyl diphosphate

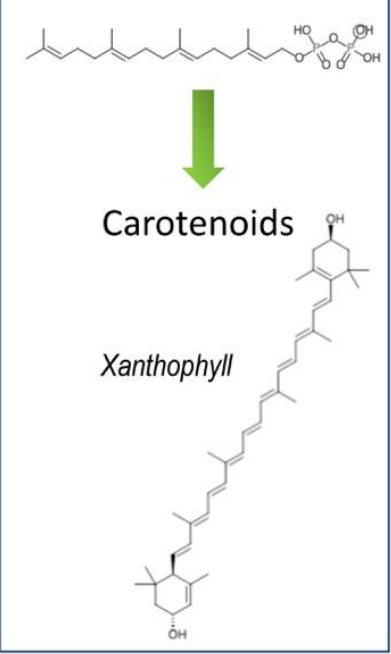

Figure 2. First, intermediary and final steps of the biosynthetic pathway of anthocyanins, with the example of Delphinidin-3-glucoside (A), betalains, with betacyanin and betaxanthin (B) and carotenoids, with the example of xanthophyll (C). The colour of anthocyanidins depends on the number of hydroxyl groups on the B-ring: the larger the number of hydroxyl groups,

the bluer the colour (Tanaka et al. 2008). In the carotenoid biosynthesis pathway, both isopentenyl pyrophosphate and dimethylallyl diphospate (not pictured in the figure) undergo a series of condensation reactions producing geranylgeranyl diphosphate, the precursor of carotenoids (Nisar et al. 2015). Structures were obtained from PubChem through ScribMol

(http://www.librairiedemolecules.education.fr/outils/scribmol/scrib.html). 

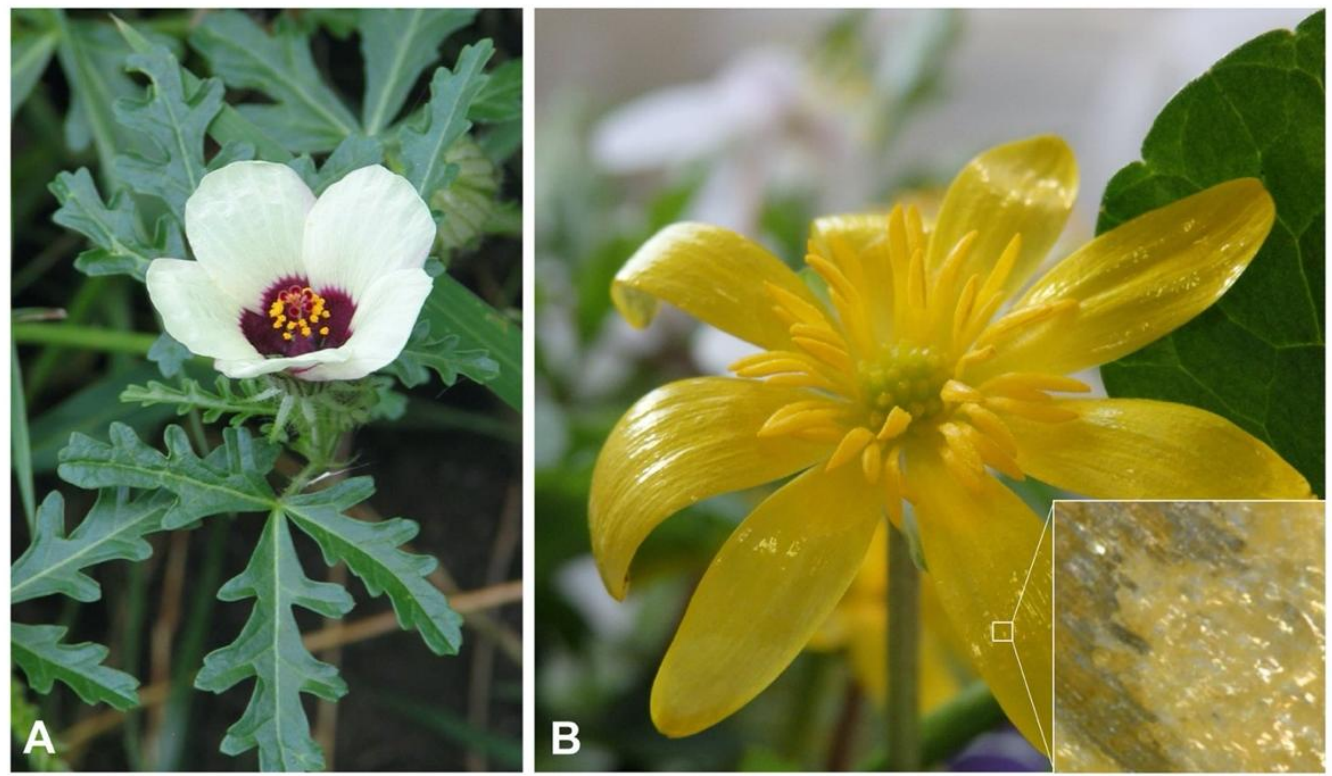

Figure 3. Examples of flowers producing structural colours on their petals. A. The iridescent flower of Hibiscus trionum L. (Malvaceae). The dark zone on each petal has a striated epidermis that produces iridescence by light diffraction. Photograph: Wikipedia. B. The petals of Ficaria verna Huds. (Ranunculaceae) appear glossy because their very thin and flat upper epidermis, rich in pigment (close-up), reflects light in an effective way. Photograph: S. Nadot
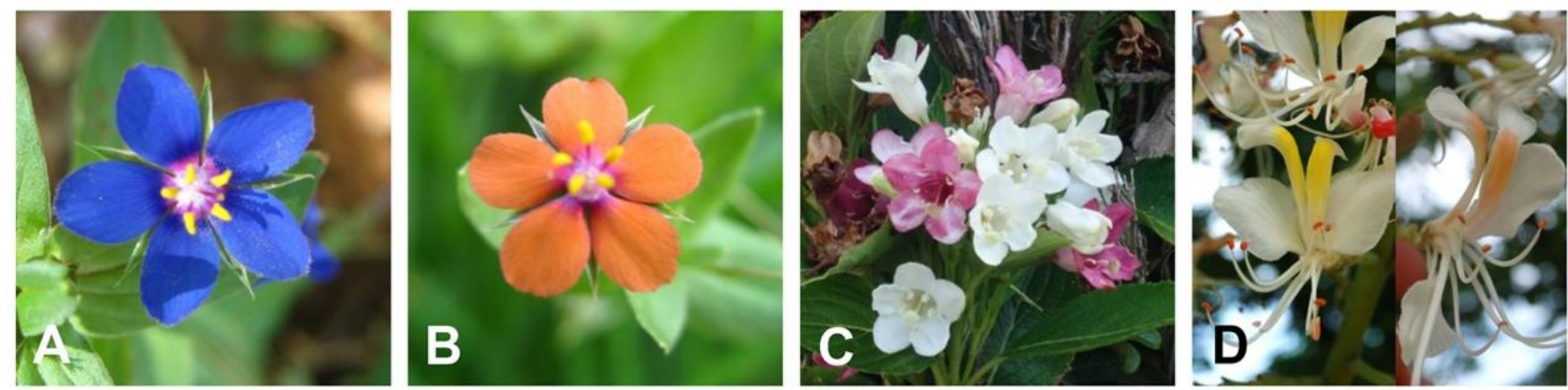

Figure 4. Examples of flowers displaying colour variation over space or time. A and B. Blue and red flowers of Lysimachia arvensis (L.) U.Manns \& Anderb. (Primulaceae). The blue form is widespread in the Mediterranean area, while the red form is common in Northern Europe. C. Flower colour change in Weigela coraeensis Thunb. (Caprifoliaceae): white flowers have not yet been pollinated. D. The same phenomenon in Aesculus hippocastanum L.

(Sapindaceae): the upper petals of the zygomorphic flowers have a yellow mark (flower on the left) that turns orange and pink when the flower has been pollinated (flower on the right). 